\title{
The Role of Trust and Procedural Justice in Enhancing Organizational Citizenship Behavior
}

\author{
Henny Suharyati*, Rais Hidayat, Sumardi, Haki Rodian Abidin \\ Prodi Administrasi Pendidikan, Sekolah Pascasarjana \\ Universitas Pakuan \\ Bogor, Indonesia \\ *henny.suharyati@unpak.ac.id
}

\begin{abstract}
This study aims is to increase the role of trust and procedural justice among teachers to enhance organizational citizenship behavior (OCB). Accountability and transparency in the management of school institutions will increase the credibility of institutions and build citizens' trust in school management itself. These conditions can create a conducive, comfortable work atmosphere and form job satisfaction among school residents. The urgency of this research is the importance of examining the This research is a quantitative study with a correlational approach consisting of two independent variables, namely trust and procedural fairness, and one dependent variable, namely OCB. The research was conducted at Public Elementary Schools in Gunung Putri District in 2019, with a total sample of 118 teachers who were taken proportionally by random sampling. The results of the study showed that there is a positive and significant relationship between trust and OCB, which is $59 \%$. Moreover, there is a significant relationship between procedural justice (X2) and OCB which contributes 44\%. Also, there is a positive and significant relationship between trust and procedural justice together with $\mathrm{OCB}$, which is $63 \%$. Based on these things, it can be concluded that the OCB can be improved through increasing trust and procedural justice.
\end{abstract}

Keywords-trust, procedural justice, organization citizenship Behavior

\section{INTRODUCTION}

School is an organization that must be designed as best as possible so that the implementation of education can run effectively and efficiently so that the specified educational goals can be achieved. One who plays an important role in determining the success of education in schools is the teacher. Teachers should educate, train and guide students so that they become dignified human beings. Therefore, we need teachers who have good performance so that the learning process can take place well too. Such a human profile is expected following the objectives of national education, which can become the next generation who are smart and qualified in facing the future challenges of the nation and state of the Republic of Indonesia.

Quality education and learning do not depend on just one component, namely the teacher, but other components in the form of learning implementation programs, students, learning facilities and pre-learning facilities, funds, environment, and the atmosphere at school. All components of the learning system determine the success of achieving educational goals, but all of these components will not run optimally for students if they are not supported by teachers who are able to educate and transfer knowledge properly.

In the context of organizational behavior, the performance needed by the school organization is not only intra-role performance, which only fulfills the main tasks in the job description. More than that, teachers must be able to perform other roles that support the achievement of overall institutional performance. Teachers must be able to provide added value (value-added) to the organization, which can be represented in the form of developing good behavior for school members.

To advance education and the quality of human resources, educational institutions in Indonesia need OCB. If you want to achieve organizational goals, high OCB is needed. Considering that OCB is very important and useful, every teacher must develop it in schools. If all teachers already have OCB well, it will create a comfortable atmosphere and full of kinship so that the organization will be able to run well, and it will have an impact on improving the quality of education.

One of definition about OCB is explained by Newstrom and Davis which states that good behavior of organizational citizens is often characterized by spontaneity, voluntary nature, which has a constructive impact on results, is an unexpected help to others, and it is an additional role [1]. The OCB behavior described above is more directed at the psychological state of co-workers, where spontaneity and volunteerism are part of one's soul's calling to help others based on sincerity. The definition of OCB according to McShane and Von Glinow states that OCB is a variety of forms of cooperation and valuable assistance to others who support organizational relationships and psychological conditions [2]. Individual psychological conditions will encourage the creation of healthy social interactions within the organization. To encourage cooperation and a spirit of help among members of the organization. So that the solidity of solidity between citizens will indirectly increase their performance in the organization. 
According to Robbins and Judge, job satisfaction is a major determinant of OCB behavior [3]. A teacher who is satisfied with a task tends to speak positively about the organization, help other fellow teachers, and pass normal expectations in their assignment. Besides, teachers who are satisfied in carrying out tasks are easier on the job because they want to respond to their positive experiences. Another factor that affects OCB is the organizational climate [4]. The nature of the teacher who persists in accepting circumstances or situations in an organizational environment will create optimal behavior so that they can complete their work better, even exceeding the specified standards.

Furthermore, OCB can be influenced by work commitment. The higher the organizational commitment that the teacher has towards the place where he works, the higher the OCB will be. Likewise, on the contrary, the lower the organizational commitment that the teacher has towards the place where he works, the lower the OCB will be [5].

McShane and Von Glinow's view positions OCB from a broader role perspective [6]. According to them, the role of OCB is not only limited to technical "physical" activities but also includes conceptual activities within the organization. The conceptual aspect is the involvement of citizens in expressing strategic thinking and ideas to advance the organization. Contributions of thought, for example, provide constructive advice, build the abilities and capabilities of partners in work and spread a good influence on the community. Contributions of this thought can occur across sectors and outside the official scope of one's work within the organization. This action will allow an individual to demonstrate his intellectual capacity and dedication to the advancement of the institution. Of course, this assistance does not automatically get compensation in return or financial benefits from the organization. But this contribution can become the attention of the leadership so that it can build a positive image concerned in the organization.

The essence of OCB behavior is the values that exist naturally in each person. His actualization in work will have a positive impact on his place of work. This is an advantage for organizations that employ employees who have these values. However, OCB behavior can also be built by an organization as a nurture behavior by being trained and formed by the institution to create its organizational culture in the context of a positive image of the organization to the community.

Based on the explanation of the concepts from these experts, it can be synthesized that the good behavior of organizational citizens (OCB) is the voluntary behavior of organizational citizens in helping their partners without taking into account the rewards when doing tasks outside their obligations, where this behavior can encourage increased institutional performance. as a whole, which has indicators of helper behavior, in good community, sportsmanship, contributions, willingness to organize, personal initiative, selfdevelopment.

Accountability and transparency in the management of the school institution will raise the credibility of the institution and will build the trust of citizens in the school management itself. Then a mutual trust is built between school members and between leaders. This condition can create a conducive, comfortable work atmosphere and create job satisfaction among school members. So, in such conditions, school members, including teachers, will try their best to devote all their potential and abilities, to work optimally in carrying out education, even without taking into account the wages and benefits for all the dedication they give. The most basic aspect is the low mastery of information and communication technology for teachers, which affects the Organization Citizenship Behavior of teachers in schools.

Robbins and Coulter suggest that trust is defined as a belief in the integrity, character, and abilities of a leader [7]. The meaning of this trust is more specific in the profile of the leader. Followers who believe in the leadership are willing to empower their interests to the leadership because they believe that their rights and interests will not be abused.

Robbins and Coulter describe the dimensions of trust based on research results, that five dimensions form the concept of trust: 1) integrity, honesty and truth, 2) competence, technical knowledge and interpersonal skills and, 3) consistency, reliability, assurance, and good decisions in handling situations; 4) loyalty, willingness to protect someone, physically and emotionally, 5) openness, willingness to share ideas and information freely [7].

The dimensions of trust according to Colquitt and Salam consist of, 1) Competence, which is carried out by conveying to others that they believe in the abilities and capabilities of communicators, regarding delivering promises, achieving goals, and leading effectively; 2) Integrity, where the expectations of the communicator will be attached to the high level of ethics and morals in general; 3) Can be trusted (dependability), knowing that a person can be measured what he said he can do; 4) Good deeds (Benevolence), ensuring that one's greatest interests will always be remembered [8].

Based on the exposure of these experts, it can be synthesized that trust is a good presumption that is built based on belief in others who are considered capable of realizing common goals and interests, who have indicators of positive expectations (positive expectation), willing to obey (Vulnerable), honest (honest), loyal (loyal), believe (belief), and reliable (dependability).

Gibson defines organizational justice as the level where an individual feels treated equally in the organization where he works [9]. Colquitt argues that organizational justice has four types, namely distributive justice, procedural justice, interpersonal justice, and informational justice [8]. According to Colquitt, the type of organizational justice has its respective advantages. According to Dyne and Graham (2005), an organization can be said to be fair if in making decisions, members of the organization are allowed to voice their opinions and views [10]. Also, after the decision is made, if the implementation of the decision is judged the same for each employee, then the employee will feel that there is justice. 
Procedural justice is a concept in issuing various decisions in determining policies related to the sustainability of the institution. But how the policymaking process itself is determined, this will be a special discussion that is unique, because each institution has different characteristics and organizational culture. This includes the procedural mechanism approach adopted in determining policies in the institution.

The definition of procedural justice according to Miner which states procedural justice is a reasonable assumption of the procedures used to make decisions [11]. This opinion is more general, where all decisions must be based on existing rules of the game, such as providing opportunities to convey aspirations and input in a consistent decision-making process, making decisions can be corrected, and reducing irregularities.

A more specific opinion is explained by George and Jones, which states that procedural justice is related to the perceived sense of justice regarding the procedures used to make policies regarding equal distribution of income results [12]. The opinion referred to by George and Jones is a policy that is not limited only to financial equity, but also concerns the method of evaluating the level of work performance, as well as how to handle complaints and disputes [12]. Reaction to procedures depends more on how honesty and appropriateness the procedure is perceived to be, rather than the amount of fairness that occurs in reality.

The position of the procedural justice function is clearly explained by Daft that procedural justice is the concept of placing the rules clearly and enforcing them consistently and in a balanced way [13]. It aims to regulate justice-oriented organizational governance for all parties in the institution. Based on the explanation of the concepts from these theorists, it can be synthesized that procedural justice is the sense of justice felt by organizational citizens regarding the institution's policy-making process based on honesty, fairness, and the accuracy of decision-making methods in accordance with the agreed rules and code of ethics, resulting in the birth of the policy. acceptable to all members of the organization, with indicators of equality of treatment (equitable treatment), the accuracy of procedures (procedures used), balanced rules (impartially rules), the fairness of the process (fairness), and providing feedback (feedback offered).

This study aims to improve the good behavior of school organization members (OCB) among teachers through teachers' trust in their school institutions and procedural justice. Specifically, this study aims to increase OCB through the following variables: to identify the strength of the relationship between trust and OCB, the relationship between procedural justice and $\mathrm{OCB}$, the relationship between trust and procedural fairness with $\mathrm{OCB}$

\section{METHODS}

The method used in this research is a survey method with correlational techniques, which is a type of research that seeks to reveal the relationship between two independent variables and one dependent variable. The research variable consisted of two independent variables, namely Trust (X1), Procedural Justice (X2) and the dependent variable was organizational citizenship behavior (OCB) (Y). The relationship between the three variables is described in figure 1 .

The target population of this study was all State Elementary School (SDN) teachers in Bogor Regency. The affordable population to be studied is scattered in Gunung Putri District. The total teacher population is 167 teachers. The samples were determined randomly, using a proportional random sampling technique which was done by drawing the sample candidates.

The data collection technique used a questionnaire that was conducted on three research variables, namely trust (X1), procedural justice (X2), and organizational citizenship behavior (Y). The questionnaire will be answered by teachers who represent their schools in Gunung Putri District as mentioned above figure 1 .

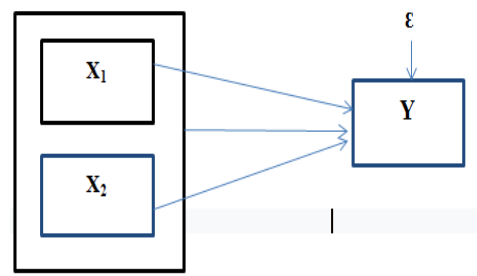

Fig. 1. Constellation of Relationship between Research Variables: Variable X1 (Trust), Variable X2 (Procedural Justice), Variable Y (Organizational Citizenship Behavior) and variable $\Sigma$ (other variables)

\section{RESULTS AND DISCUSSION}

The data used as the basis for the description of the results of this study is the score of the instrument items which refers to the three research variables, namely Organizational Citizenship Behavior (OCB) (Y) as the dependent variable and two independent variables, namely trust (X1) and procedural justice (X2). This research data description is intended to provide an overview of the distribution or distribution of data. The data is processed using descriptive statistical techniques consisting of the mean (mean), middle score (median), frequent scores (mode), standard deviation (standard deviation), frequency distribution (variance), lowest and highest scores, the range between the lowest and highest scores (range), data diversity (sample variance), the total score (sum), number of classes and class ranges accompanied by histogram graphs of the three research variables.

From calculations using the Liliefors test, it is obtained that the Lcount $=0.0543$, while from the Liliefors table for $\alpha=0.05$ and $\mathrm{n} \mathrm{118}$, the value of Ltable $=0.0824$ is obtained. Because the value of Lcount <Ltable, then $\mathrm{H} 0$ is accepted, which means that it provides a conclusion, namely the standard error of the Organization Citizenship Behavior (OCB) estimates of trust from a normally distributed population (figure 2). 


\begin{tabular}{|c|c|c|c|}
\hline Galat & Lcount & $\begin{array}{c}\text { Ltable } \\
\alpha=0,05\end{array}$ & Conclusion \\
\hline $\mathrm{Y}-\hat{\mathrm{Y}}_{1}$ & 0,0543 & 0,0824 & Normal \\
\hline $\mathrm{Y}-\hat{\mathrm{Y}}_{2}$ & 0,0614 & 0,0824 & Normal \\
\hline \multicolumn{4}{|c|}{ Normal distribution requirements: Lcount < Ltable } \\
\hline
\end{tabular}

Fig. 2. Summary of estimated standard error normality test with liliefors.

Calculations using the Liliefors test obtained Lcount $=$ 0.0614 while from the Liliefors table for $\alpha=0.05$ and $n 118$ the value of Ltable $=0.0824$ was obtained. Because the value of Lcount <Ltable, then $\mathrm{HO}$ is accepted, which means that it provides a conclusion, namely the standard error of the Organization Citizenship Behavior (OCB) estimation for procedural justice comes from a normally distributed population.

The homogeneity test of the data variance of the Organizational Citizenship Behavior (OCB) variable on trust (X1) was tested using the Bartlett test (Table 2). Based on the calculation results, the value $\chi 2$ count $=38.0779$ while $\chi 2$ table $=144.3537$ is obtained. Homogeneous data requirements $\chi 2$ count $<2$ table, thus Organizational Citizenship Behavior (OCB) (Y) and confidence data (X1) come from populations that have the same variance (homogeneous) (figure 3 ).

\begin{tabular}{|c|l|c|c|c|}
\hline No & \multicolumn{1}{|c|}{ Grouping } & $\chi 2$ count & $\begin{array}{l}\gamma 2 \text { table } \\
\alpha=0,05\end{array}$ & Conclusion \\
\hline 1 & $\begin{array}{l}\text { Y on the basis of } \\
\text { X1 }\end{array}$ & 38,0779 & 144,354 & Homogen \\
\hline 2 & $\begin{array}{l}\text { Y on the basis of } \\
\text { X2 }\end{array}$ & 28,9762 & 144,354 & Homogen \\
\hline \multicolumn{4}{|c|}{ Homogeneous population requirements $\gamma 2$ count $<\gamma 2$ table } \\
\hline
\end{tabular}

Fig. 3. Homogeneity test summary with the Bartlet test.

The calculation of the correlation in increasing the two trust variables (X1) with organizational citizenship behavior (OCB) (Y) using regression analysis techniques based on the calculation process of SPSS version 23. After analyzing the correlation between trust to increase organizational citizenship behavior (OCB), the functional relationship equation is obtained $\hat{\mathrm{Y}}=28.337+0.902 \mathrm{X} 1$, which means that the constant (a) is 28.337 meaning that if trust (X1) is 0 , the organizational citizenship behavior (OCB) (Y), the value is 28.337. The functional-coefficient (b) of the trust variable (X1) is 0.902 , meaning that if trust (X1) has increased by one-unit, organizational citizenship behavior (OCB) (Y) has increased by 0.902 units.

\section{A. Trust (X1) can Increase Organizational Citizenship Behavior $(O C B)(Y)$}

The results showed "there is a positive and significant relationship between trust and organizational citizenship behavior (OCB)". This is shown by the results of the analysis using the product-moment technique, the correlation coefficient of ry. $1=0.7672$ is obtained. With a strong level of relationship. While the contribution value (coefficient of determination) trust (X1) to organizational citizenship behavior (OCB) (Y) is calculated based on the correlation coefficient $r=0.7672$ used as the coefficient of determination, namely $\mathrm{r}^{2}=(\text { ry.1 })^{2}=$ 0.5886, meaning the variable trust (X1) contributed to organizational citizenship behavior (OCB (Y) by the remaining $59 \%$ by other factors.

These results are in line with the results of research by Marsellani and Mudji Rahardjo which resulted in the finding that the correlation coefficient between trust and organization citizenship behavior (OCB) reached $r=0.293$ [14], which means that there is a relationship between trust and organizational citizenship behavior (OCB). This is following the statement of Ivancevich et al which explains that the major influence associated with OCB in leadership is something that employees receive from their leaders [15]. Primarily, the growing trust between employees and their leaders, as well as a management style that encourages the development of leadership skills among employees is proven to improve OCB's behavioral attributes.

Based on these results, school management needs to gain the trust of teachers in the school, as well as trust in school management which encourages increasing the behavioral attributes of OCB. It can be concluded that there is a positive increase between trust in OCB, so that trust is an important factor in efforts to increase OCB, the higher the trust, the higher the organization citizenship behavior (OCB), and vice versa, the lower the trust, the lower the organization citizenship behavior (OCB).

\section{B. Procedural Justice (X2) can Increase Organization Citizenship Behavior (OCB) (Y)}

The results showed "there is a positive and significant relationship between procedural justice and organization citizenship behavior (OCB). This is indicated by the results of the analysis using the product-moment technique, the correlation coefficient is obtained ry. $2=0.6647$. With a strong level of relationship. While the contribution value (coefficient of determination) procedural justice (X2) to organizational citizenship behavior (OCB) (Y) is calculated based on the correlation coefficient $r=0.6647$ used as the coefficient of determination, namely $\mathrm{r}^{2}=(\text { ry. } 1)^{2}=0.4418$ means the variable justice procedural $(\mathrm{X} 2)$ contributed to organizational citizenship behavior (OCB (Y) by $44 \%$ and the rest by other factors.

This is consistent with the statement of Gibson et al which states that there is a positive impact on several reactive tendencies and behaviors in the workplace [9]. In other words, when workers feel a high degree of procedural fairness towards the allocation and budgeting policies in the organization, they are most likely: committed to the organization, motivated from within, staying in the organization, engaging in good behavior of organizational citizens (OCB), trusting in leadership, 
displaying seriousness of effort in their duties, and carry out their job properly.

Based on the results of the above research, it can be concluded that procedural justice makes a significant contribution to organizational citizenship behavior (OCB). The higher the procedural justice, the higher the organizational citizenship behavior (OCB), and conversely the lower the procedural justice, the lower the organizational citizenship behavior (OCB).

\section{The Relationship Between Organizational Citizenship Behavior (OCB) together with Trust (X1) and Procedural Justice (X2)}

The results showed "there is a positive and significant relationship between trust and procedural justice together with organizational citizenship behavior (OCB)".

The multiple correlation calculation using the productmoment correlation technique between trust and procedural justice with organizational citizenship behavior (OCB) produces a correlation coefficient of $\mathrm{R}=0.7916$, meaning that this value shows that there is a positive relationship between trust and procedural justice together with the organization. citizenship behavior (OCB) has been verified.

Meanwhile, the contribution value (determination coefficient) of trust (X1) and procedural justice (X2) on organizational citizenship behavior (OCB) $(\mathrm{Y})$ is calculated based on the correlation coefficient $\mathrm{r}=0.7916$ used as the coefficient of determination, namely $\mathrm{r}^{2}=(\text { ry.1.2) })^{2}=0,6267$ means that the variable trust (X1) and procedural justice (X2) contributes to organizational citizenship behavior (OCB) (Y) by $63 \%$, the remaining by other factors.

McShane and Von Glinow state that procedural justice is as important as distribution justice where both of them affect organizational commitment, trust, various forms of resignation, and other aggressive behavior [2]. So, on the other hand, if there is no trust built between teachers and school principals, it is likely that there will be a non-conducive situation in the organization which will damage the performance of the institution as a whole and ultimately harm the institution.

From the research results, it can be concluded that trust (X1) and procedural justice (X2) make a significant contribution to organizational citizenship behavior (OCB) (Y). The higher the trust and procedural fairness, the higher the organizational citizenship behavior (OCB), and conversely the lower the trust and procedural fairness, the lower the organizational citizenship behavior (OCB).

\section{CONCLUSION}

Based on the analysis of the research data, it can be concluded that efforts have been found to improve the organization citizenship behavior (OCB), through the identification and strengthening of the relationship between the research variables. There is a positive and significant relationship between trust (X1) and organization citizenship behavior (OCB) (Y) so that through trust can increase organization citizenship behavior (OCB). There is a positive and significant relationship between procedural justice (X2) and organization citizenship behavior (OCB) (Y), so that through procedural justice it can improve organization citizenship behavior (OCB. Also, there is a positive and significant relationship between trust $(\mathrm{X} 1)$ and procedural justice (X2) together with organization citizenship behavior (OCB) (Y), so that through trust and procedural fairness together it can increase organization citizenship behavior (OCB).

\section{ACKNOWLEDGMENT}

This research was carried out with Grant Funds from the Directorate of Community Service Research, Directorate General of Research and Development Strengthening of the Ministry of Research and Technology following the implementation year 2020 based on Funding Agreement between L2Dikti4 Office and Pakuan University Number: 114/AMD/SP2H/LT /MONO/LL4/PP/ 2020 April 1st, 2020. Thus, we thank the Kemenristekdikti/BRIN for funding.

\section{REFERENCES}

[1] J.W. Newstrom, K. Davis, and J.L. Pierce, "Organizational Behavior: Human Behavior at Work," 1993.

[2] S. McShane and M.A. Von Glinow, Organizational behaviour: Emerging knowledge and practice for the real world. McGrawHill/Irwin, 2010.

[3] S.P. Robbins, Organizational Behavior: Stephen P. Robbins, Timothy A Judge. Pearson, 2013.

[4] A.T. Fanis and F. Rahmi, "Pengaruh Iklim Organisasi Terhadap Organizational Citizenship Behavior Pada Karyawan Bank X,' J. RAP (Riset Aktual Psikol. Univ. Negeri Padang), vol. 7, no. 1, pp. 1-11, 2017.

[5] N.N.T. Suwandewi and D.K. Sintaasih, "Keadilan Organisasional Dan Komitmen Organisasional: Efeknya Pada Organizational Citizenship Behavior," E-Jurnal Manaj., vol. 5, no. 7, 2016.

[6] S.L. McShane, M.A.Y. Von Glinow, and R. Jing, "Organizational Behavior," Irwin/McGraw-Hill, 2000.

[7] S.P. Robbins and M. Coulter, Management. Upper Saddle River -New Jersey: Prentice Hall. Indiana: Lawrence Erlbaum Associates, 1997.

[8] J. Colquitt, J.A. Lepine, and M.J. Wesson, Organizational Behavior: Improving Performance and Commitment in the Workplace (4e). New York, NY, USA: McGraw-Hill, 2014.

[9] J. Gibson, J. Ivancevich, and R. Konopaske, Organizations: Behavior, structure, processes. McGraw-Hill Higher Education, 2011

[10] L. Van Dyne, J.W. Graham, and R.M. Dienesch, "Organizational Citizenship Behavior: Construct Redefinition, Measurement, and Validation,” Acad. Manag. J., vol. 37, no. 4, pp. 765-802, 1994.

[11] J.B. Miner, Organizational Behavior: Essential theories of motivation and leadership. one, vol. 1. ME Sharpe, 2005.

[12] J.M. George, G.R. Jones, and W.C. Sharbrough, Understanding and managing organizational behavior. Pearson Prentice Hall Upper Saddle River, NJ, 2005.

[13] R.L. Daft, Organization theory \& design. Cengage learning, 2020.

[14] M.M. Anggraini and M. Rahardjo, "Peran Keadilan Prosedural, Kepercayaan, Kepuasan Kerja Dan Komitmen Organisasi Dalam Meningkatkan Organizational Citizenship Behavior (OCB)(Studi Pada Karyawan PDAM Kabupaten Demak)," Diponegoro J. Manag., vol. 5, no. 4, pp. 1-14, 2016.

[15] J.M. Ivancevich, M.T. Matteson, and R. Konopaske, "Organizational Behavior and Management," 1990. 